\title{
Commemoration of the Discovery of Radium
}

$\mathrm{W}$ ITH the "Semaine internationale contre le Cancer", which took place at Paris between November 23 and 30, the fortieth anniversary of the discovery of radium by Pierre and Madame Curie was commemorated. Simultaneously, the discovery of the electron, the X-rays, and Hertzian waves was celebrated. The importance of recent discoveries, which are now occupying the attention of contemporary workers, is easily over-estimated; and, making due allowance for this possibility, we feel justified in considering the discovery of radium to be one of the outstanding events of the history of science. It promoted to a higher degree than any other discovery the development of the science of radioactivity, which has so deeply influenced our outlook on the nature and formation of the chemical elements, and simultaneously supplied a tool of outstanding importance alike to various branches of science and to medicine.

France is rightly proud of a great son, French by birth, and a great daughter, French by adoption, and has solemnly commemorated the fortieth anniversary of the discovery of radium. The opening of the "Semaine internationale contre le Cancer" took place at the Sorbonne. The broadcast of the President of the Polish Republic from Warsaw, in which the memory of the great daughter of Poland and her achievements were recalled, was eloquently answered by M. Lebrun, President of the French Republic. Among those present were also Mme. Dluska, the sister of Mme. Curie, and the latter's daughters Irène and Eve, Miss Johanna Hertz, daughter of the late Heinrich Hertz, and the Marchesa Marconi.

The gathering was also addressed by various representatives of the French Government, and on scientific topies by Jean Perrin, Maurice de Broglie and Langevin, who gave a short survey of the physics of the electron, the X-rays and Hertzian waves respectively, while Gutton described the technical application of the Hertzian waves, and Gendrean gave an eloquent description of the life-work of Pierre and Marie Curie.

The addresses delivered on the following days dealt with biological and physical topics, with the exception of that of Rowntree, who discussed the efforts made in Great Britain in cancer therapy. Schinz discussed the possibilities and limits of the treatment of cancer by use of various radiations. The utilization of biological reactions in measuring X-ray doses was the subject of a lecture by Carter Wood, who has found in the eggs of Drosophila the most suitable biological material. The application of radioactive indicators in biology was discussed by Hevesy, that of the electron microscope by Marton, while Errera spoke on the effect of Hertzian waves on macromolecules. Bernal's lecture dealt with the elucidation of the structure of the virus by the use of X-rays. Several physical topics were discussed as well. The only surviving assistant of the lato Heinrich Hertz, Prof. Bjerknes, gave an illuminating survey of Hertz's work. Louis de Broglie gave a lecture on the wave character of the electron, followed by G. P. Thomson, who discussed the phenomena of electron diffraction and its applications. Several lectures dealt with technical topics, including a lecture by Bouwers, who discussed the production of different kinds of penetrating radiation, mentioning the construction of a sealed X-ray tube at Eindhoven operated at one million volts.

The lectures were given at the Palais de la Découverte, which contains such a wealth of exhibits showing the trend of scientific progress in the most diverse fields in an unsurpassingly inspiring and instructive way-a fitting frame for the celebration of the fortieth anniversary of the discovery of radium. G. H.

\section{The Imperial Bureau of Dairy Science}

$\mathrm{I}^{\mathrm{N}}$ 1936 the British Commonwealth Scientific Conference which met in London to consider the working of the organizations controlled by the Executive Council of the Imperial Agricultural Bureaux, recommended that a new Imperial Bureau of Dairy Science be established. The conference also suggested the National Institute for Research in Dairying as the most suitable place for the Bureau.

Following agreement by all the authorities concerned, the new Imperial Bureau of Dairy Science has now been established at Shinfield, near Reading. Prof. H. D. Kay, director of the National Institute for Research in Dairying, has been appointed director of the Bureau. Mr. W. G. Sutton, from Massey Agricultural College, New Zealand, has been appointed deputy director and has now taken up his duties. The Bureau is financed co-operatively by the Governments of the British Empire in the same way as the other Imperial Agricultural Bureaux.
The functions of the Bureau are to index research work in dairy science, whether carried out in the Empire or elsewhere ; to collect, abstract and collate information bearing on dairy science and to distribute such information both by publication and by private communication to research workers, officials and advisory officers throughout the Empire. In addition the Bureau is charged with the duty of establishing and maintaining contact between research workers with common interests, promoting conferences of workers and visits to research centres, and in general encouraging the circulation of information, ideas, material and personnel.

The field of dairy science to be covered by the Bureau was defined by the Conference when recommending its establishment. This field includes the microbiology, chemistry and physics of milk and its products; animal diseases in so far as they affect milk and its products; the technology of processing milk and manufacturing dairy products; the 